\title{
Experimental Infection with Koi Ranavirus (KIRV) of Common Carp (Cyprinus carpio L.) and Rohu (Labeo rohita H.)
}

\author{
D. Kaviarasu ${ }^{1 *}$, K. Riji John², M. Rosalind George ${ }^{1}$, B. Ahilan ${ }^{3}$, \\ P. Padmavathy ${ }^{4}$ and M. Petchimuthu ${ }^{1}$
}

${ }^{1}$ Department of Fish Pathology and Health Management, Fisheries College and Research Institute, Tamil Nadu Dr. J.Jayalalithaa Fisheries University, Thoothukudi, Tamil Nadu, India

${ }^{2}$ Fisheries, Kerala University of Fisheries and Ocean Studies Panangad, Kochi, India

${ }^{3}$ Dr. M.G.R. Fisheries College and Research Institute, Tamil Nadu Dr. J.Jayalalithaa Fisheries University, Ponneri, Tamil Nadu, India

${ }^{4}$ Department of Aquatic Environment Management, Dr. M.G.R Fisheries College and Research Institute, Dr. J.Jayalalithaa Fisheries University, Thalainayeru, Tamil Nadu, India

*Corresponding author

\section{A B S T R A C T}

\begin{tabular}{l} 
Key w or d s \\
KIRV, Common \\
carp, Rohu, \\
$\begin{array}{l}\text { Polymerase chain } \\
\text { reaction, Cell } \\
\text { culture assay, } \\
\text { Histopathology }\end{array}$ \\
\hline $\begin{array}{l}\text { Article Info } \\
\text { Accepted: } \\
\text { 22 October } 2020 \\
\text { Available Online: } \\
\text { 10 November } 2020\end{array}$ \\
\hline
\end{tabular}

The aim of this study was to determine the pathogenicity of koi ranavirus (KIRV) in common carp (Cyprinus carpio L) and rohu (Labeo rohita $\mathrm{H}$ ). In the present study, common carp and rohu fingerlings were experimentally infected with KIRV by intraperitoneal injection with $50 \mu \mathrm{l}$ of the virus preparation having an infectious dose of $10^{6.9}$ TCID50/ml. After injection, tissues such as spleen and kidney of both challenged fishes with the virus were collected at 3, 7, 14, 21 and $28 \mathrm{dpi}$ for investigation by polymerase chain reaction (PCR), cell culture assay and histopathological technique. KIRV was detected in pooled samples of kidney and spleen collected from both challenged fishes after 3 dpi by PCR, while no positive results were obtained from all other time points. In cell culture assay no cytopathic effect was observed in the EPC (Epithelioma papulosum cyprini) cell line at all time points of both fish species for virus reisolation. The results of the histopathological analysis showed necrosis and hypertrophy in kidney tissue of common carp and necrosis and detachment of glomeruli from the epithelium of tubules in kidney tissue of rohu at 3 and $7 \mathrm{dpi}$, while no typical pathological changes were observed in spleen tissue of common carp at all time points and melanomacrophage cells were observed in spleen tissue of rohu at $3 \mathrm{dpi}$. On the whole, results reveal that there is no clear clinical pathology observed in common carp and rohu fingerlings following experimental infection with KIRV.

\section{Introduction}

Aquaculture production has increased prominently in South East Asian countries during the last decade. Viral diseases cause serious problems in finfish aquaculture and 
are one of the most critical factors in the fish farming sector. Viruses in the family Iridoviridae have emerged over the last two decades to become important pathogens in the intensively raised finfish aquaculture sector. Ranaviruses belonging to the family Iridoviridae causes significant morbidity and mortality among the ectothermic vertebrates like amphibians, fish and reptiles (Chinchar et al., 2011). Ranavirus is now recognized as major emerging threat to economically and ecologically important cold-blooded vertebrates (Williams et al., 2005) infecting at least 14 families with about 70 amphibian species, more than 100 fish species and dozens of reptiles (Chinchar, 2002; Robert et al., 2011). Ranavirus infection cause significant morbidity and mortality in ectothermic vertebrates like fish, amphibians, and reptiles for the period of past 30 years (Chinchar et al., 2009, 2011). Ranavirus are large icosahedral, double-stranded DNA (dsDNA) viruses, 120-200 $\mathrm{nm}$ in diameter in size and with a genome size of 105 and 140 $\mathrm{kbp}$ that can infect a broad range of lower vertebrates (Holopainen, 2012).

The genus Ranavirus consists of six officially identified species such as Ambystoma tigrinum virus (ATV), Bohle iridovirus (BIV), Epizootic haematopoietic necrosis virus (EHNV), European catfish virus (ECV), Frog virus 3 (FV3) and Santee-Cooper ranavirus (SCRV) with FV3 being recognised as the type species of the genus (Jancovich et al., 2012). EHNV was the first ranavirus isolated from fish during a disease outbreak of redfin perch (Perca fluviatilis) and rainbow trout (Salmo gairdneri) in Australia (Langdon, 1989; Langdon et al., 1988). Recently, a marine ranavirus (similar damselfish virus, SRDV) has been reported to be causing high mortalities in seabass (Lates calcarifer) and similar damselfish ( $P$. similis) fingerlings (Sivasankar et al., 2017). The first documentation to the isolation of virus resembling Santee-Cooper ranavirus infection in koi was reported from India (George et al., 2015), where the corresponding viral agent was detected and successfully isolated and named as koi ranavirus (KIRV). The aim of the study was to determine the susceptibility of common carp and rohu to KIRV. The study involved experimental infection with clinical pathology, confirmation of the results by $\mathrm{PCR}$, reisolation of the virus in cell culture and histopathology.

\section{Materials and Methods}

\section{Virus strain and propagation}

Koi ranavirus (KIRV) isolated from koi (Cyprinus carpio L) was used for (George et al., 2015) experimental study. Epithelioma papillosum cypini (EPC) cell line was used for isolation, propagation and infectivity assay of the virus. The cell line was maintained in Leibovitz-15 (L-15) medium (Gibco, USA) supplemented with 10\% fetal bovine serum (Gibco, USA) and 1x antibioticantimycotic solutions (Gibco, USA) in $25 \mathrm{~cm}^{2}$ cell culture flasks (Thermo, Korea) at $27^{\circ} \mathrm{C}$. On completion of CPE, the infected culture supernatant was harvested and clarified by centrifugation at $1500 \mathrm{~g}$ for $15 \mathrm{~min}$ (Fig. 1). Clarified supernatant held at $4{ }^{\circ} \mathrm{C}$ was titrated in EPC cells.

\section{Experimental fish}

Common carp (Cyprinus carpio L) fingerlings (mean length of $7.59 \mathrm{~cm}$ and mean weight $6.54 \mathrm{~g}$ ) and rohu (Labeo rohita) fingerlings (mean length of $7.14 \mathrm{~cm}$ and mean weight $6.32 \mathrm{~g}$ ) were obtained from procured from national fish seed farm at Manimuthar, Tamil Nadu and maintained in the laboratory until non-specific mortalities had stopped. Fish were acclimatized to the glass tank of $100 \mathrm{~L}$ capacity maintained with $50 \mathrm{~L}$ freshwater at a temperature of $29 \pm 1^{\circ} \mathrm{C}$ and fed with commercial pelleted feed twice daily. Tanks were provided with continuous aeration and 
cleaned daily by siphoning out waste material along with partial water exchange (10-20\%). The fish was tested for the presence of koi ranavirus by PCR and was conformed negative before the experimental infection started.

\section{Experimental challenge}

Two groups consisting of 30 fish each in duplicate were used for experimental infection (Fig. 2). Prior to challenge, the fish was sedated using benzocaine at a concentration of $40 \mathrm{mg} / \mathrm{l}$. Experimental fishes were administered $50 \mu \mathrm{l}$ of cell culture grown KIRV stock ( $10^{6.9}$ TCID $_{50} /$ volume inoculated) by intraperitoneal (i.p) injection while control group received same amount of L-15 medium from the supernatant of an uninfected cell culture medium was injected. Tissues samples such as kidney and spleen were taken from three fish in each treatment at 3, 7, 14, 21 and 28 days after injection and samples were analysed by molecular method, cell culture assay and histopathological technique.

\section{Virus reisolation}

Samples of kidney and spleen tissue from common carp and rohu were aseptically removed, pooled and examined for after experimental infection. Pooled tissue extracts were inoculated into the EPC cells following standard virus isolation procedures (Amos, 1985).

Homogenised tissue samples were diluted to $1 / 10(\mathrm{w} / \mathrm{v})$ in L-15 medium containing $10 \%$ FBS and 1x antibiotic-antimycotic mix. Homogenised tissue extract was clarified by centrifugation at $3000 \mathrm{~g}$ for $15 \mathrm{~min}$ and the supernatant passed through a $0.22 \mu \mathrm{m}$ sterile disposable filter. The pellet with little amount of supernatant was subjected to PCR analysis with diagnostic primer developed from KIRV-MCP to assay the presence and the absence of the virus in both group of experimental fish sample.

\section{Detection of viral DNA from experimental fish by PCR}

DNA from KIRV injected fish tissues from the experimental challenge study was extracted using $1 \mathrm{ml}$ of DNA extraction solution (Himedia) as per the manufacturer's instructions. The extracted DNA was dissolved in $100 \mu \mathrm{l}$ of sterilized deionised water (Thermo) and stored at $4^{\circ} \mathrm{C}$ before use. The DNA extracted from KIRV injected and control fish were used for PCR in $25 \mu \mathrm{l}$ reaction mixture with Smart Prime Mix (Ampliqon, Denmark). Specific primers and cycling conditions to KIRV; MCPFORW and MCPREV set (George et al., 2015) were used for PCR amplification. The PCR amplified products along with molecular markers stained by ethidium bromide were visualized in $1.5 \%$ agarose gels by a gel documentation system (Biorad, U.S.A).

\section{Histopathology}

Tissues of gill, kidney and spleen from experimental fish without clinical signs and from control fish were excised and fixed in $10 \%$ neutral buffered formalin for at least 24 $\mathrm{h}$ or preserved until process of histology. The tissues were processed routinely, embedded in paraffin wax, sectioned, and stained with haematoxylin and eosin (HE) and and examined by bright-field microscopy.

\section{Results and Discussion}

Ranaviruses are recognized as important and emerging multi-host pathogens with very broad host ranges (Gray et al., 2009). The movement of animals out from original geographical region brings together with new host species and potential pathogens, facilitates host-switching and continues the 
cycle for disease emergence (Peeler et al., 2011). Being a virus of recent origin in a commercially important fish in India, there was urgent need to find the susceptible hosts among the cultured species in India. In this study therefore we determined the experimental transmission and pathogenicity of koi ranavirus (KIRV) in common carp and rohu widely cultivated carp species in India.

\section{Clinical pathology}

Host susceptibility to viral infection is not a specific trait for a susceptible animal because susceptibility to disease is influenced by a complex interaction of host, pathogen and environmental factors (Tweedell and Granoff, 1968). Infection by ranavirus results in mortality and morbidity different from species to species. Some of the experimental challenge study and field data show that mortality can range from low (e.g. 0\%) to $100 \%$ of infected animals of an experimental test group depending on species, virus and age and health condition of the host following short infection times (Hyatt et al., 1998; Pearman et al., 2004; Harp and Petranka, 2006). In the present study, we observed no specific external clinical signs and mortality during the experimental period. The target viral DNA was detected from the tissues of both experimental fish species after virus injected fish sampled at 3 dpi by PCR. However, we could not detect specific DNA of KIRV from tissues of both experimental fish species sampled at later periods. Experimental infections and clinical signs may vary according to various factors. In general, differences on the time of transmission, age of fish and route of infection are the important factors for pathogenicity of virus (Aranguren et al., 2002).

Ranaviruses infection differs due to the varied dynamics among the host species and viral isolate and the detailed molecular mechanisms by which ranaviruses are able to cause disease and circumvent the host immune response are not completely understood (Allen et al., 2017). Not all diseases caused by ranaviruses always result in mortality (Miller et al., 2009). However, some field studies confirmed that individuals can be sublethally infected with ranaviruses (Brunner et al., 2004, Pearman et al., 2004, Greer et al., 2009). While the relationship between viral load and ranaviral disease is currently not well understood (Gray et al., 2009), there is less evidence that they are correlated (Hoverman et al., 2010). High variation in susceptibility of amphibians, fish, and chelonians to ranaviruses has been reported by (Hoverman et al., 2011). Variations in host susceptibility to different ranavirus pathogens create an ideal scenario for the pathogen to move between hosts, utilizing highly susceptible species and also low susceptible hosts for amplification and for persistence respectively (Gray et al., 2009).

\section{Cell culture assay}

Ranavirus isolated from marine damselfish was found to be growing well in marine and freshwater fish cell lines derived from seabass and snakehead (Sivasankar et al., 2017). They have also re-isolated ranavirus using cell culture from the pooled homogenates of the spleen and kidney of each of the dead and moribund seabass fingerlings which had experimentally infected. In contrast, in our study, the virus could not be reisolated from the spleen and kidney of the both experimental virus infected fish species indicating that the virus could have been either eliminated by the fish or reduced the load that evaded detection using cell cultures.

\section{PCR detection}

Tissues such as spleen and kidney of common carp and rohu challenged with KIRV were 
collected at 3, 7, 14, 21 and $28 \mathrm{dpi}$ and diagnosed for the presence of KIRV by PCR. PCR detected the target MCP amplicon indicating the presence of KIRV in pooled samples of kidney and spleen from experimental group fishes of common carp and rohu after 3 dpi. However, no positive results were obtained from other sampling time points of 7, 14, 21 and 28 dpi (Fig. 3). PCR detection of the infected fish tissues showed that the viral DNA is present in the infected tissues such as spleen and kidney of the koi (George et al., 2015).

Fig.1 Cytopathic effect induced by KIRV in EPC cell lines (A) EPC Control (x 200) (B) KIRV infected EPC cell line (x 200)
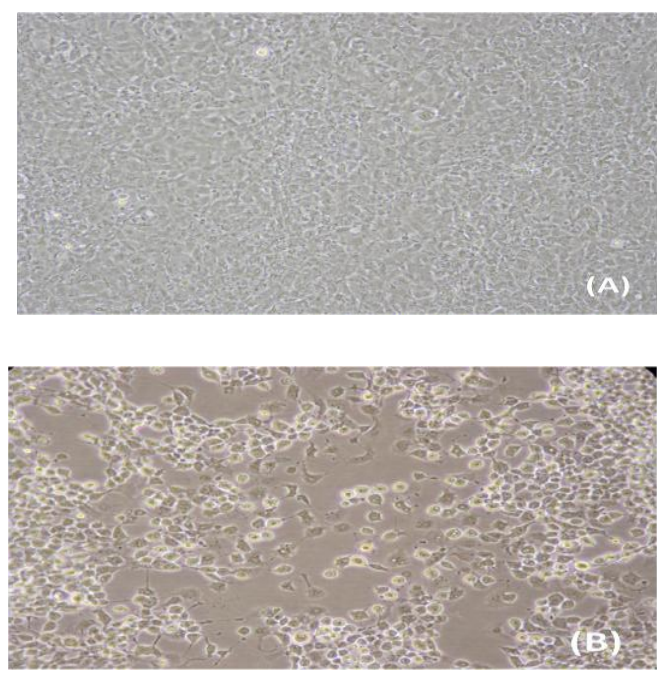

Fig.2 Experimental setup for koi ranavirus (KIRV) experimental infection to common carp and rohu

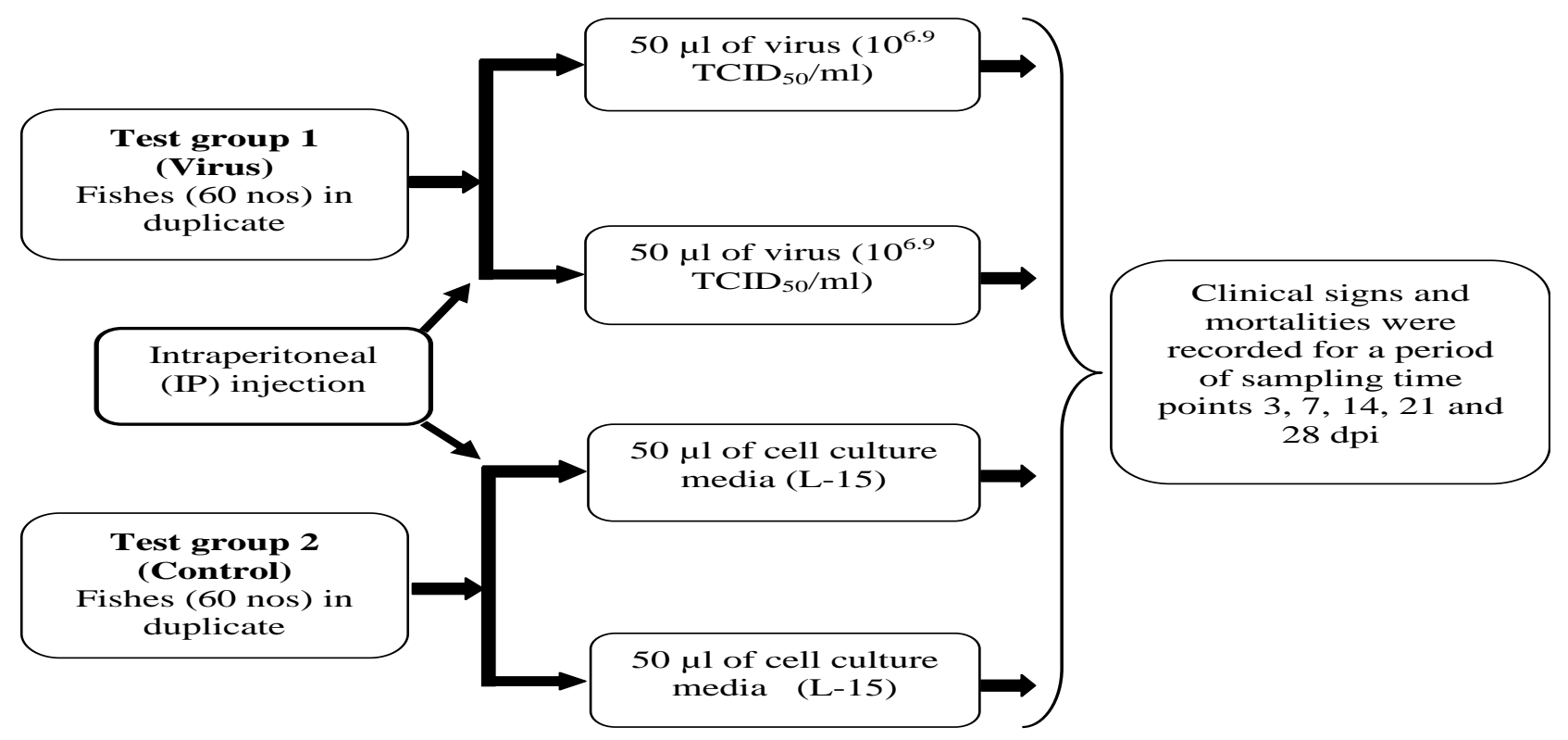


Fig.3 Agarose gel electrophoretic analysis for detection of KIRV in tissues samples collected from control and virus groups at 3, 7, 14, 21 and 28 dpi by PCR. (A) Common carp experiment Lane $3 \& 4$ positive sample (virus group in duplicate sample), Lane 13\&24- Positive control, Lane 14\&25- Negative control, Lane 15\&26-100bp marker and (B) Rohu experiment - Lane $3 \& 4$ positive sample (virus group in duplicate sample), Lane 13\&24- Positive control, Lane 14\&25-

Negative control, Lane 15\&26-100bp marker
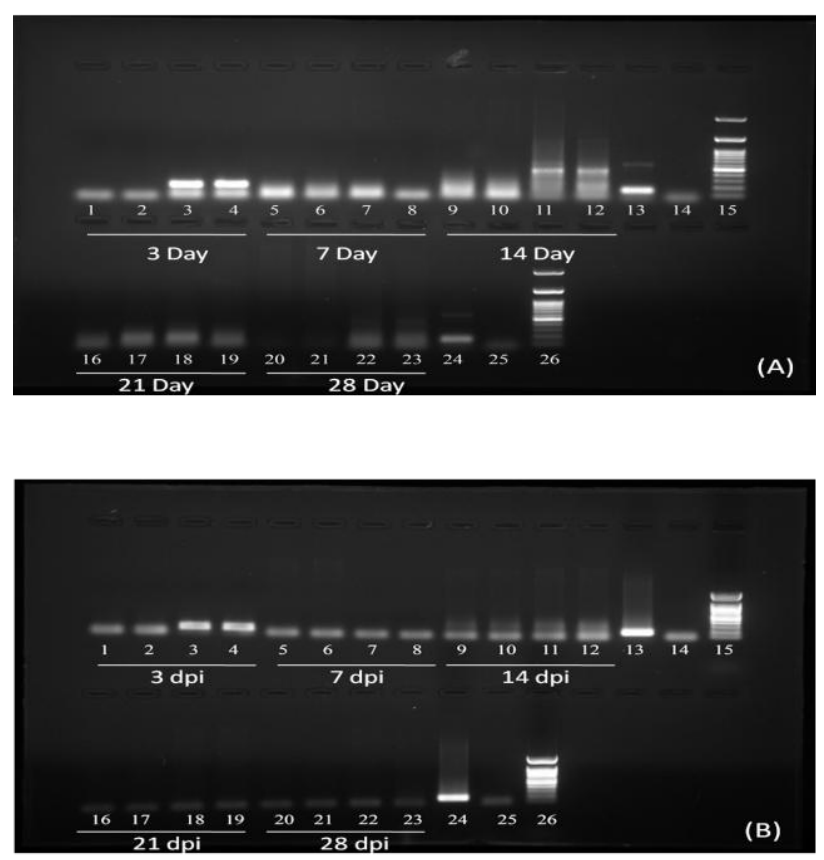

Fig.4 Common carp kidney: (A) necrosis and hypertrophy in tubules at 3 dpi and (B) necrosis and hypertrophy in kidney tubules at 7 dpi HE (100x)
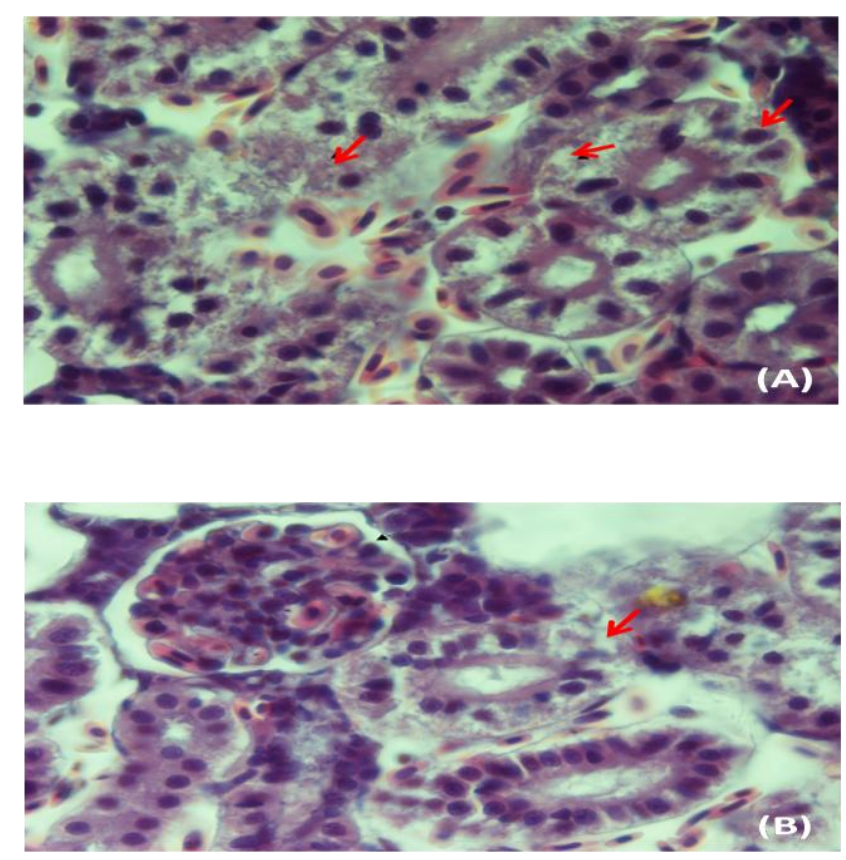
Fig.5 Rohu kidney: (A) Necrosis at 3 dpi and (B) detachment of glomeruli from epithelium of tubules at 7 dpi $\mathrm{HE}(60 \mathrm{x})$
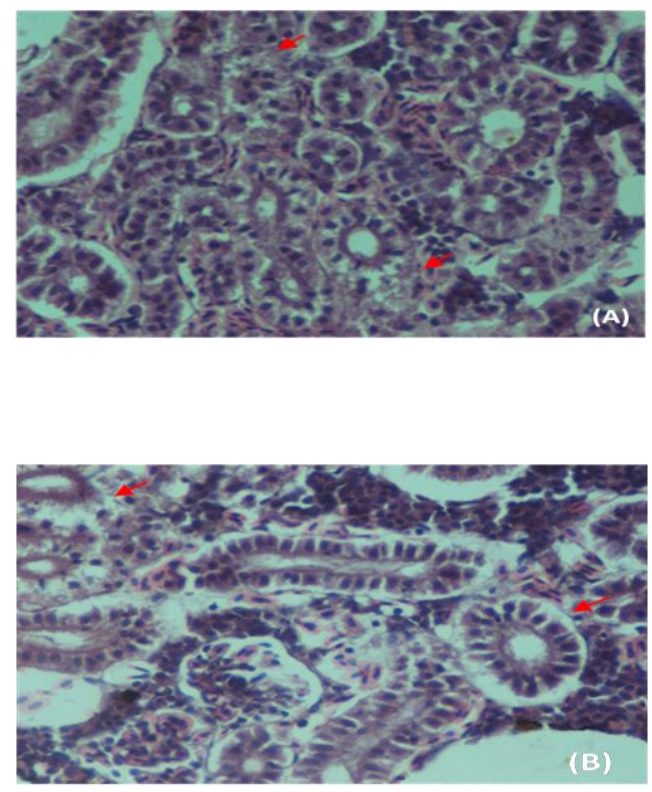

Fig.6 Rohu spleen: Melanomacrophage center observed in spleen at 3 dpi HE (60x)

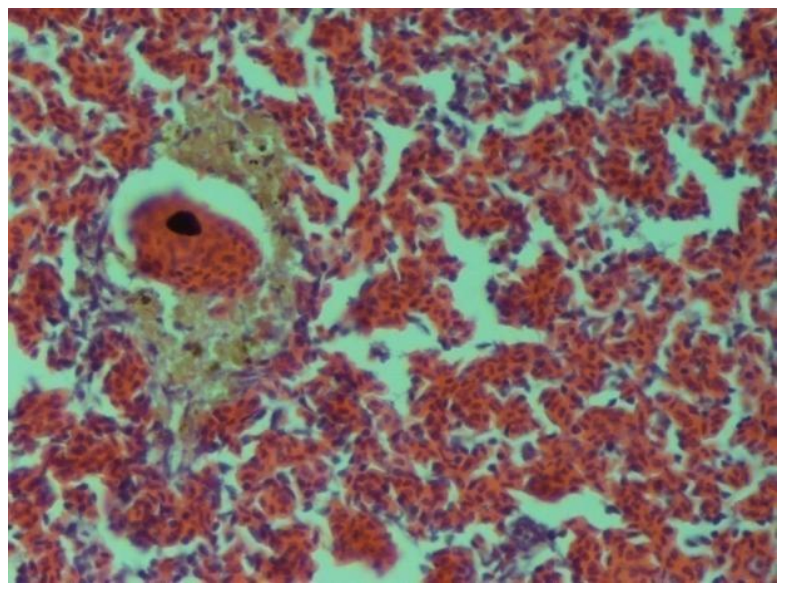

\section{Histopathology analysis}

Gobbo et al., (2010) have reported that histopathology was not always performed during disease outbreaks or in experimental trials with ranavirus. There are 10 different families represented among the 14 fish host species potentially susceptible to EHNV infection but the susceptibility does not appear to correlate with taxonomic relationships (Jensen et al., 2011; Gobbo et al., 2010). Zilberg et al., (2000) reported necrosis of the gastrointestinal (GI) mucosal epithelium, gills, and heart in largemouth bass (Micropterus salmoides) experimentally infected with Santee - Cooper ranavirus. Our results of the histopathological study revealed the necrosis and hypertrophy in kidney tubules of common carp with infected KIRV (Fig. 4) and also necrosis and detachment of 
glomeruli from the epithelium of tubules in kidney tissue of rohu infected with KIRV infected at 3 and 7 dpi (Fig. 5). Unfortunately, there was no any pathological change observed in kidney collected from both common carp and rohu at 14, 21 and 28 dpi. In spleen tissue also not showed typical histopathological changes at all the time points in common carp. While in rohu experiment, melanomacrophage centers were observed in the spleen of experimentally infected fish at 3 dpi (Fig. 6) and no typical histopathological changes observed in spleen at other time points. Reports indicate that there are 10 different families represented among the 14 fish host species potentially susceptible to EHNV infection but the susceptibility does not appear to correlate with taxonomic relationships (Gobbo et al., 2010; Jensen et al., 2011).

In conclusion the several diseases induced by members of the genera Ranavirus have been responsible for mortality in captive and wild amphibian, reptile and fish populations around the globe over the past two decades. Ranaviruses are now recognized as emerging pathogens causing acute and systemic diseases in various host animals like fishes, amphibians and reptiles. The present study was to provide evidence to determine the experimental transmission and pathogenicity of koi ranavirus (KIRV) to common carp, Cyprinus carpio $\mathrm{L}$ and rohu, Labeo rohita. This investigation indicated that there is no gross mortality or any specific external pathological changes observed in common carp and rohu fingerlings following experimental infection with KIRV.

\section{Acknowledgments}

Authors are grateful to the National Surveillance programme for Aquatic Animal Diseases (sub project no -21) ICAR-NBFGR, Lucknow for the funding support to carry out the study. The study formed the part of the $\mathrm{Ph} . \mathrm{D}$ thesis of the first author.

\section{References}

Allen AG, Morgans S, Smith E, Aron MM, Jancovich JK (2017): The Ambystoma tigrinum virus (ATV) RNase III gene can modulate host PKR activation and interferon production. Virology. 511:300-8. doi: 10.1016/j.virol.2017. 08.013.

Amos KH (1985): Procedures for the detection and identification of certain fish pathogens, 3rd Ed. Fish Health Section, American Fisheries Society, Bethesda, MD.

Aranguren R, Tafalla C, Novoa B, Figueras A (2002) Experimental transmission of encephalopathy and retinopathy induced by nodavirus to sea bream, Sparus aurata L., using different infection models. J Fish Dis 25:317324. doi.:10.1046/j.1365-2761.2002.

Brunner JL, Schock DM, Davidson EW, Collins JP (2004): Intra specific reservoirs: complex life history and the persistence of a lethal ranavirus. Ecology. 85(2):560-6.doi:10.1890/020374.

Chinchar VG (2002): Ranaviruses (family Iridoviridae); emerging coldblooded killers. Arch Virol. 147:447470. doi:10.1007/s007050200000.

Chinchar VG, Hyatt A, Miyazaki T, Williams $\mathrm{T}$ (2009): Family Iridoviridae: poor viral relations no longer. InLesser known large dsDNA viruses (pp. 123170). Springer, Berlin, Heidelberg.

Chinchar VG, Yu KH, Jancovich JK (2011): The molecular biology of frog virus 3 and other iridoviruses infecting coldblooded vertebrates. Viruses. 3(10):1959-85. doi: 10.3390/v3101959.

George MR, John KR, Mansoor MM, Saravanakumar R, Sundar P, Pradeep 
V (2015): Isolation and characterization of a ranavirus from koi, Cyprinus carpio L., experiencing mass mortalities in India. Journal of fish diseases. 38(4):389-403. doi:10.1111/jfd.12246

Gobbo F, Cappellozza E, Pastore MR, Bovo G (2010): Susceptibility of black bullhead Ameiurus melas to a panel of ranavirus isolates. Diseases of aquatic organisms. 90(3):167-74. doi: $10.3354 /$ dao02218.

Gray MJ, Miller DL, Hoverman JT (2009): First report of ranavirus infecting lung less salamanders. Herpetological Review. 40(3):316.

Greer AL, Brunner JL, Collins JP (2009): Spatial and temporal patterns of Ambystoma tigrinum virus (ATV) prevalence in tiger salamanders Ambystoma tigrinum nebulosum. Diseases of aquatic organisms. 85(1): 1-6. doi:10.3354/dao02061.

Harp EM, Petranka J W (2006): Ranavirus in wood frogs (Rana sylvatica): potential sources of transmission within and between ponds. Journal of wildlife diseases, 42(2), 307-318. doi:10.7589/0090-3558-42.2.307.

Holopainen R, Tapiovaara H, Honkanen J (2012): Expression analysis of immune response genes in fish epithelial cells following ranavirus infection. Fish \& shellfish immunology. 32:10951105. doi:10.1016/2012.03.011.

Hoverman JT, Gray MJ, Haislip NA, Miller DL (2011): Phylogeny, life history, and ecology contribute to differences in amphibian susceptibility to ranaviruses. EcoHealth. 8(3):301-19. doi: 10.1007/s10393-011-0717-7.

Hoverman JT, Gray MJ, Miller DL (2010): Anuran susceptibilities to ranaviruses: role of species identity, exposure route, and a novel virus isolate. Diseases of aquatic organisms. 89(2):97-107. doi:10.3354/dao02200.

Hyatt AD, Parkes H, Zupanovic Z (1998): Identification, characterisation and assessment of Venezuelan viruses for potential use as biological control agents against the cane toad (Bufo marinus) in Australia: a report from the Australian Animal Health Laboratory, CSIRO, Geelong, Australia. May 1998.

Jancovich JK, Chinchar VG, Hyatt A, Miyazaki T, Williams T, Zhang QY (2012): Family Iridoviridae. In: Virus Taxonomy: Ninth Report of the International Committee on Taxonomy of Viruses. Edited by. A.M.Q. King, M.J. Adams, E.B. Carstens and E.J. Lefkowitz. pp. 193-210. Elsevier, San Diego, EE.UU.

Jensen BB, Holopainen R, Tapiovaara H, Ariel E (2011): Susceptibility of pikeperch Sander lucioperca to a panel of ranavirus isolates. Aquaculture. 313(14):24-30. doi:10.1016/2011.01.036.

Langdon JS (1989): Experimental transmission and pathogenicity of epizootic haematopoietic necrosis virus (EHNV) in redfin perch, Perca fluviatilis L., and 11 other teleosts. J. Fish Dis., 12, 295-310. doi:10.1111/j.1365-2761.1989.

Langdon JS, Humphrey JD, Williams LM (1988): Outbreaks of an EHNV-like iridovirus in cultured rainbow trout, Salmo gairdneri Richardson, in Australia. Journal of Fish Diseases. 11(1):93-6.doi:10.1111/j.1365-2761.

Miller DL, Gray MJ, Rajeev S, Schmutzer AC, Burton EC, Merrill A, Baldwin CA (2009) Pathological findings in larval and juvenile anurans inhabiting farm ponds in Tennessee, USA. J Wildl Dis 45:314-324. doi:10.7589/00903558-45.2.314.

Pearman PB, Garner TW, Straub M, Greber UF (2004): Response of the Italian agile frog (Rana latastei) to a 
Ranavirus, frog virus 3: a model for viral emergence in naive populations. Journal of Wildlife Diseases. 40(4):660-9. doi:10.7589/0090-355840.4.660.

Pearman PB, Garner TW, Straub M, Greber UF (2004): Response of the Italian agile frog (Rana latastei) to a Ranavirus, frog virus 3: a model for viral emergence in naive populations. Journal of Wildlife Diseases. 40(4):660-9. doi:10.7589/0090-355840.4.660.

Peeler E, Thrush M, Dunn P (2011): Routes of disease introduction to, and spread from, freshwater salmonid farms in England and Wales - gathering expert opinion. Finfish News 11, 9-15.

Robert J, George E, Andino FD, Chen G (2011): Waterborne infectivity of the Ranavirus frog virus 3 in Xenopus laevis. Virology. 417(2):410-7. doi: 10.1016/j.virol.2011.06.026.

Sivasankar P, John KR, George MR,
Mageshkumar P, Manzoor MM, Jeyaseelan MP (2017):

Characterization of a virulent ranavirus isolated from marine ornamental fish in India. Virus disease. 28(4):373-82. doi: 10.1007/s13337-017-0408-2.

Tweedell K, Granoff A (1968): Viruses and renal carcinoma of Rana pipiens. V. Effect of Frog Virus 3 on developing frog embryos and larvae. J Natl Cancer Inst 40:407-410. doi: 10.1093/jnci/ 40.2.407.

Williams T, Barbosa-Solomieu V, Chinchar VG (2005): A decade of advances in iridovirus research. Adv Virus Res. 65:173-248. doi:10.1016/S00653527(05)65006-3.

Zilberg D, Grizzle JM, Plumb JA (2000): Preliminary description of lesions in juvenile largemouth bass injected with largemouth bass virus. Diseases of aquatic organisms. 39(2):143-6. doi:10.3354/dao039143.

\section{How to cite this article:}

Kaviarasu, D., K. Riji John, M. Rosalind George, B. Ahilan, P. Padmavathy and Petchimuthu, M. 2020. Experimental Infection with Koi Ranavirus (KIRV) of Common Carp (Cyprinus carpio L.) and Rohu (Labeo rohita H.). Int.J.Curr.Microbiol.App.Sci. 9(11): 3234-3243. doi: https://doi.org/10.20546/ijcmas.2020.911.388 